\title{
In memoriam: Donald H. Gilden, M.D.
}

\author{
Howard L. Lipton ${ }^{1} \cdot$ Ken Tyler $^{2}$
}

Received: 6 September 2016 / Accepted: 6 September 2016/Published online: 28 September 2016

(C) Journal of NeuroVirology, Inc. 2016

Donald Harvey Gilden, M.D., died on August 22, 2016, in hospice care surrounded by his family in Denver, Colorado. He was 78 and had battled renal cell cancer for 16 months yet worked regularly on research almost to the end. Don's commitment to and passion for research was celebrated with his Pioneer in NeuroVirology Award in 2007. His dedication to future research and his colleagues was evident in the detailed, written instructions left regarding his NIH Program Project grant on the molecular pathogenesis of varicella zoster virus (VZV) infection that he had directed for 28 years. Don also prided himself in being a practical yet thorough clinical diagnostician, and he displayed unconditional, positive regard for his patients.

Don was an inveterate optimist with a fiercely independent mindset who was also quick to question what he viewed to be dogma. Professionally, he will be remembered for being the Chairman of the Department of Neurology at the University of Colorado School of Medicine for nearly a quarter of a century until 2009 when he stepped down and was recognized for his clinical teaching and his research on VZV. His research focused on VZV latency and clinical manifestations upon reactivation. Don's talents were not confined to the medical profession. He played semi-professional baseball the summer before entering college, was a life-long, expert

Howard L. Lipton

hlipton@uic.edu

1 Department of Microbiology \& Immunology and Department of Neurology, University of Illinois at Chicago, 835 South Wolcott Avenue, Chicago, IL 60612-7344, USA

2 Department of Neurology, University of Colorado Denver School of Medicine and Anschutz Medical Center, Aurora, CO 80045, USA skier, and was a dedicated violinist who practiced each morning before work and performed at professional gatherings.

Don received his undergraduate education at Dartmouth, his medical degree at the University of Maryland, and completed residency training in Neurology at the University of Chicago before becoming a postdoctoral neurovirology fellow with Neal Nathanson at The Johns Hopkins School of Public Health. He excelled in medicine and research and later received the University of Chicago's Alumni Award for Distinguished Service, election to the Johns Hopkins Society of Fellows and the Medical Association of the University of Maryland's Honor Award and Gold Key.

After fellowship Don joined the faculty of the Wistar Institute and the University of Pennsylvania Department of Neurology, attaining the rank of Professor. Don was mentored by the Institute's Director Hilary Koprowski with whom he developed a friendship and shared a love for classical music. In 1986, Don became the Chair of Neurology at the University of Colorado, a position he held with distinction. After retiring as Chair, Don continued to direct his productive virology research group.

Don published over 400 papers, reviews, and chapters in the medical and scientific literature. Early on, Don believed that multiple sclerosis was caused by a persistent viral infection, and he worked on this possibility for many years. The issue of viral persistence led him to begin working on VZV infection. Perhaps no other individual contributed more to our understanding of VZV and its role in clinical diseases than Don. He and his colleagues established that VZV DNA was present in normal human cranial and dorsal root, as well as autonomic ganglia, throughout the neuraxis. They showed that latent VZV DNA is circular and is associated with histone proteins 
Fig. 1 Don Gilden performing at the 3rd International Symposium on NeuroVirology in San Francisco, California, September, 2000

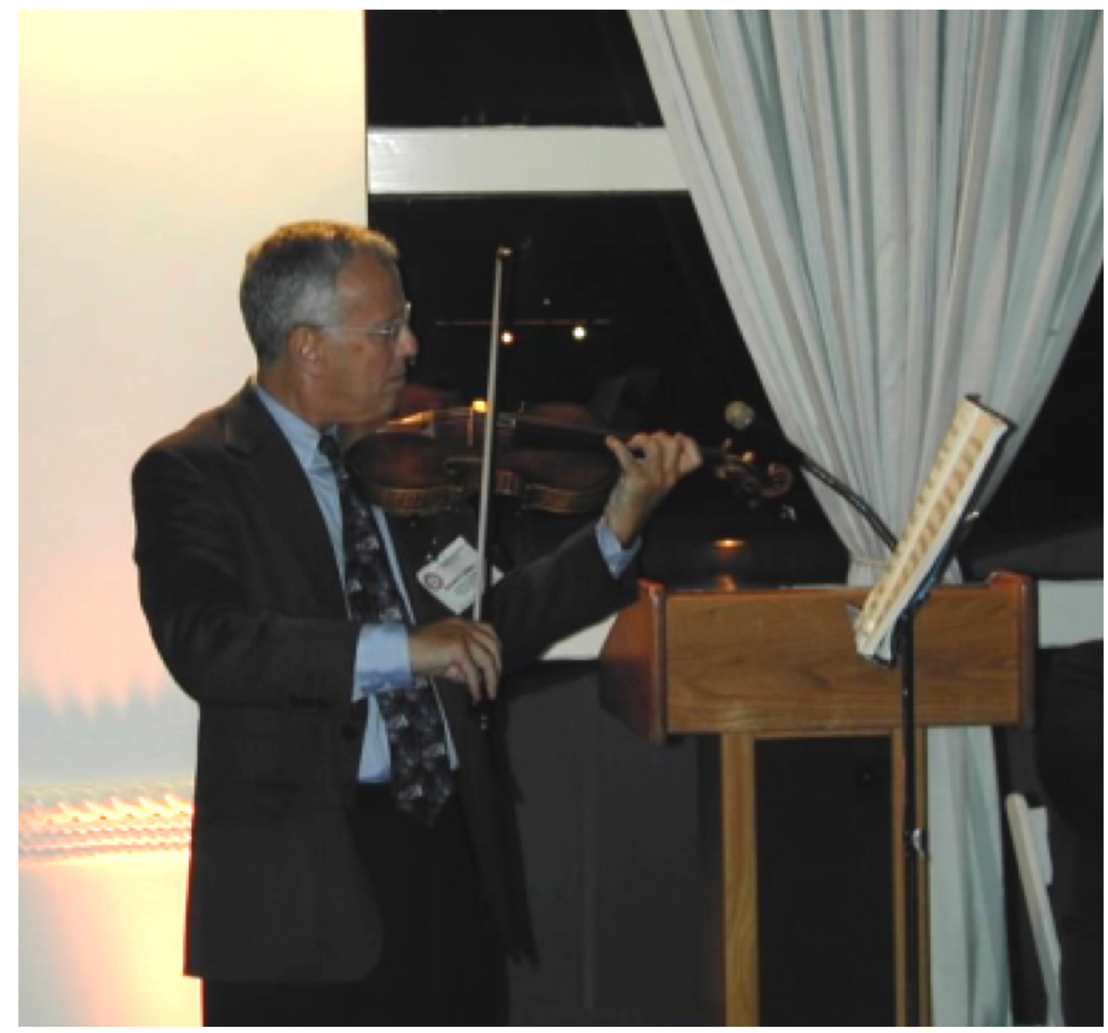

that help regulate virus gene expression in human ganglia. Don and his colleagues established simian varicella virus infection in monkeys as the only animal model that accurately recapitulates human VZV primary infection, laten$\mathrm{cy}$, and reactivation. Don also identified zoster sine herpete (shingles pain without rash) as a clinical entity. Don showed that productive VZV infection in cerebral arteries produced strokes, or VZV vasculopathy-a sepa- rate entity from VZV encephalitis. In the last few years, he expanded the spectrum of VZV vasculopathy to include giant cell (temporal) arteritis and granulomatous aortitis. From this experience, Don assumed that the full spectrum of multi-system disease caused by VZV is yet to be discovered.

We know he will be missed by his family but also by his many students, trainees, colleagues and friends. 